BIBLIOGRAPHY

Abboud, M. A., and Abdin, Z. H. (1954). Gaz. Egypt. paediat. Ass., $2,71$. (1946). The Vitamins in Medicine, 2nd ed. Heinemann, London.

Clarke, B. R. (1952). Causes and Prevention of Tuberculosis. Livingstone, Edinburgh.

Faber, K. (1938). Acta tuberc. scand., 12, 287

Hart, P. D'Arcy (1932). Spec. Rep. Ser. med. Res. Coun. (Lond.), No. 164. Preventive Medicine Dept. (1957). Reports of Antituberculosis Section. P.H.D., Kuwai

(1957). Reports of School Health Section. P.H.D., Kuwait.

Yelton, S. E. (1946). Publ. Hlth Red. (Wash.), 61, 1144.

\section{BEMEGRIDE ANALEPSIS}

BY

\section{A. SHULMAN, M.B., B.Sc.}

AND

GLENDA M. LAYCOCK, B.Sc.

Physiology Department, University of Melbourne

The article by Dotevall and Herner (1957) has prompted us to summarize some recent pharmacological observations concerning the safe and widespread analeptic activity of bemegride to hypnotics both structurally related and unrelated to it.

Bemegride ( $\beta$-methyl- $\beta$-ethylglutarimide) will wake mice from moderately deep acute hypnosis (ready response to pain, moderate depression of corneal reflex, sleeping time $60-80$ minutes) due to such structurally related hypnotics as barbiturates (pentobarbitone), thiobarbiturates (thiopentone), glutarimides (glutethimide ; "doriden" and others), diketopiperidines (methyprylone ; " noludar "), diketotetrahydropyridines (" persedon "), diketothiazanes ("dolitrone"), diketothiazolidines ( 5 : 5-diethyl-2 : 4-diketothiazolidine), monoureides (carbromal and bromvaletone), and succinimides (5methyl-5-phenylsuccinimide and others) (Shaw, Simon, Cass, Shulman, Anstee, and Nelson, 1954 ; Shulman, 1956; Somers, 1956; Frey, Hushahn, and Soehring, 1956 ; Kimura and Richards, 1957 ; Shulman and Laycock, 1957a, 1957b). It also antagonizes such structurally unrelated hypnotics as substituted acetamides (phenyl-diethylacetamide), saturated and unsaturated alcohols (chlorbutol, methylpentynol, " placidyl "), aldehydes (chloral hydrate), carbamates (urethane), cyclic ethers (paraldehyde), and sterols (" viadril ") (Frey et al., 1956 ; Kimura and Richards, 1957 ; Shulman and Laycock, 1957c). Its effect on deep acute hypnosis (minimal response to pain, marked depression of corneal reflex, frequent cyanosis and death, sleeping-time 2-12 hours) due to these drugs has been indicated by Kimura and Richards (1957) and Shulman and Laycock (1958). Further, bemegride will antagonize morphine-induced respiratory depression but not hypnosis or analgesia in the rabbit and dog (La Barre, 1957; La Barre, Dumont, and Desmarez, 1957; Shulman and Laycock, 1957c).

Clinical antagonism has been reported to such drugs as pentobarbitone, thiopentone, glutethimide, methyprylone, persedon, primidone, carbromal, and bromvaletone, either alone or occasionally combined with structurally unrelated hypnotics (Shulman, Shaw, Cass, and Whyte, 1955 ; Harris, 1955 ; Holten, 1956; Palmer, 1956; von Planta and Klingler, 1956 ; Dotevall and Herner, 1957).

A current quantitative investigation of this problem in mice (Shulman and Laycock, unpublished observations) indicates that at moderate levels of hypnosis the analeptic activity of bemegride to structurally related hypnotics is confined between much narrower limits than that shown to structurally unrelated hypnotics. Bemegride is generally a more potent analeptic to this latter class of substance.

We wish to emphasize the high margin of safety associated with the administration of bemegride in the relief of moderate hypnosis induced by both classes of drugs. Significant reduction in sleeping-time ( $1 \leq 0.001)$ has been obtained by the administration of mildly convulsant doses of bemegride $(20 \mathrm{mg} . / \mathrm{kg}$. each 15 minutes) to mice narcotized with hypnotics of 15 structurally different types. A few transient and minimal signs of toxicity have been occasionally observed in the case of only two drugs (urethane and $\beta$-methyl $\beta$ - $n$-amylglutarimide).

The administration of convulsant doses of bemegride $(60 \mathrm{mg} . / \mathrm{kg}$. stat. and up to 6 doses of $30 \mathrm{mg}$. $/ \mathrm{kg}$. at sevenminute intervals) to mice deeply narcotized with the same series of structurally diverse hypnotics also resulted in a significant decrease in sleeping-time $(p \leq 0.001)$ in the majority of cases (carbromal, chloral hydrate, 5:5-diethyl2:4-diketothiazolidine, dolitrone, methyprylone, methylpentynol, paraldehyde, pentobarbitone, persedon, phenyldiethylacetamide, placidyl, and viadril). Transient and mild signs of toxicity (tremors and Straub tail) followed awakening from such hypnosis due to chloral hydrate, 5:5-diethyl2:4-diketothiazolidine, dolitrone, and phenyldiethylacetamide.

Antagonism was less pronounced and toxicity more marked in the case of deep hypnosis due to urethane, glutarimide, and succinimide. At slightly higher doses of these hypnotics bemegride treatment resulted in early antagonism (corneal refiex and response to pain), followed by respiratory depression and death preceded, in the case of urethane, by severe convulsions. This potentiation was greatest in the case of $\beta$-methyl- $\beta$ - $n$-amylglutarimide, which, like bemegride, is a $\beta, \beta$-disubstituted glutarimide.

These results support the advisability of gradual titration of analeptic against hypnotic under strictly supervised conditions in an endeavour to keep the animal in the "safe state" (Shulman et al., 1955).

Although great care should be exercised in too freely extrapolating the results of these laboratory investigations to the treatment of clinical cases, it is hoped that these observations may be helpful to the clinician faced with the diagnosis and treatment of the patient in coma, particularly where self or accidental administration of hypnotics may be suspected as the underlying cause. The careful intravenous administration of bemegride (up to three 50-mg. doses at intervals of 5 to 10 minutes) would appear to be a safe and useful diagnostic and possibly therapeutic aid, especially in the young patient in whom the likelihood of cerebrovascular accident may be anticipated to be minimal and preliminary investigation of whom has rendered the diagnosis of acute metabolic disturbance unlikely.

The value of bemegride in the diagnosis of an epileptiform focus has been previously indicated (Delay, Verdeaux, Verdeaux, Drossopoulo, Schuller, and Chanoit, 1956). Additional aspects of bemegride activity have been reviewed by Shaw (1957).

\section{REFERENCES}

Delay, J., Verdetux, G., Verdeaux, J., Drossopoulo, G., Schuller, E., and Chanoit. P. (1956). Presse méd., 64. 1525.

Dotevall, G., and Herner, B. (1957). Brit. med. J., 2, 451

Frey, H. H., Hushahn, E. E. W., and Soehring, K. (1956). ArznetmittelForsch.. 6. 583.

Harris, T. A. B. (1955). Lancet, 1, 181.

Kolten, C. (1956). Ugeskr. Laes., 118, 72. Arch. int. Pharmacodyn., 110. 29.

La Barre, J. (1957). Ibid., 110, 465.

Dumont, J., and Desmarez, J. J. (1957). Ibid., 110, 452.

Palmer, K. N. V. (1956). Brit. med. j., 1, 1219 .

von Planta. P. and Klingier, M. (1956). Schweiz, med. Wschr., 86, 691. Shaw, F. H. (i957). Med. J. Aust., 1, 712 , F. H. (1957). Med. J. Aust.. 1, 712 . Anstee, J R and Nelson, B R. (1954). Nature (Lond.), 174, 402

Shulman, A. (1956). Austr. J. exp. Biol. med. Scl., 34, 471.

- and Laycock, G. M. (1957a). Ibid., 35, 421.

(1957b). Ibid. In press. (1957c). Ibid. In press.

- (1958). Ibid. In press.

Shaw, F. H., Cass, N. M., and Whyte, H. M. (1955). Brit. med. J. 1. 1238

Somers, T. C. (1956). Nature (Lond.), 178, 996. 